\title{
Study on the Runoff Characteristics of Ordovician Limestone Groundwater in Jinmen Coalmine
}

\author{
Wang Shasha \\ College of Geological Sciences \& Engineering \\ Shandong University of Science and Technology \\ Qingdao, China, 266590 \\ w275287712@126.com
}

Li Zengxue

College of Geological Sciences \& Engineering

Shandong University of Science and Technology

Qingdao, China, 266590

\author{
Wei Jiuchuan \\ College of Geological Sciences \& Engineering \\ Shandong University of Science and Technology \\ Qingdao, China, 266590
}

\author{
Song Baolai \\ JIAN YUAN Engineering Survey and Design CO., LTD, \\ Qingdao, China, 266061 \\ sblbsss@163.com
}

\begin{abstract}
Based on the data of water pumping test and releasing test, we systematically analyzed the hydrochemical characteristics of the Ordovician Limestone aquifer. We sorted the data, classified the water quality of each samples, drawed piper trilinear nomograph, and delineated hydro-chemical subsections of Ordovician limestone aquifer to analyze the Ordovician limestone aquifer water runoff features. The results shown that, Ordovician limestone groundwater flowed from the northeast, the east and the south to Tianqiao Spring. From the east boundary to the west, hydro-chemical subsections were runoff area, weak runoff area and stagnation area. Ordovician limestone groundwater flowed deeper and slower to the south of Tianqiao Springs, and the type of water quality charactered as that was in stagnant zone.
\end{abstract}

Keywords- limestone groundwater; piper trilinear nomograph; hydro-chemical characteristics; the type of water quality

\section{INTRODUCTION}

Groundwater chemical characteristics are formed by interaction between surrounding rock minerals and water flow. Storage of groundwater conditions determined its chemical composition and ion concentration ${ }^{[1]}$. In this paper, we extrapolated backward, studied on the water chemical composition and its background characteristics by water analysis, provided reference for the discrimination of water-inrushing sources.

\section{REGIONAL HYDROGEOLOGY CONDITIONS}

Shanxi karst water system contains dozens of relatively independent subsystems, and Tian Qiao Spring area is one of them, and is a totally discharging hydrogeological unit with complete process of supply, runoff and drainage. The area is about $13921.5 \mathrm{~km}^{2}$, of which there are $9607.9 \mathrm{~km}^{2}$ outcroped and half outcroped carbonate areas.

Jinmen coalfield belongs to Tian Qiao Spring area. Ordovician limestone aquifer groundwater is supplied by atmospheric precipitation in the large Ordovician limestone outcrop areas. It is also supplied by the overlying loose porous aquifers of Quaternary and Tertiary system, fissure aquifers of Permo-Carboniferous system, and surface water infiltration.

Ordovician limestone groundwater is mainly discharged to the Yellow River as the karst springs. Industrial, agricultural, and domestic consumption are also discharging forms, but water yield is relatively smaller.

\section{CHARACTERISTICS OF ORDOVICIAN LIMESTONE GROUNDWATER}

We calculated and sorted water analysis data of groundwater samples within and around the coalfield. Through further analysis of water chemical values of each samples, we confirmed hydrochemical types and belonging distributions of each samples. Water quality analysis results of water samples in Jinmen coalmine and its periphery are shown in table 1 . According to those informations, we drew the piper trilinear nomograph (Fig.1), and got groundwater horizontal hydrochemical type distribution characteristics.

TABLE I. HYDRO-CHEMICAL CHARACTERISTIC OF KARST WATER IN JINMEN MINE AND IN ADJACENT AREAS

\begin{tabular}{|c|c|c|c|c|c|c|c|c|c|c|c|}
\hline \multirow{2}{*}{ Zone division } & \multirow{2}{*}{ Sampling point } & \multicolumn{3}{|c|}{ Positive ion $/ \mathrm{mg} / \mathrm{l}$} & \multicolumn{3}{|c|}{ Negative ion /mg/l } & \multirow{2}{*}{$\mathrm{PH}$} & \multirow{2}{*}{$\begin{array}{c}\text { Total } \\
\text { hardness }\end{array}$} & \multirow{2}{*}{$\begin{array}{c}\text { Salinity } \\
/ \mathrm{mg} / 1\end{array}$} & \multirow{2}{*}{ Hydrochemical type } \\
\hline & & $\mathrm{K}^{+}+\mathrm{Na}^{+}$ & $\mathrm{Ca}^{2+}$ & $\mathrm{Mg}^{2+}$ & $\mathrm{Cl}^{-}$ & $\mathrm{SO}_{4}{ }^{2-}$ & $\mathrm{HCO}_{3}{ }^{-}$ & & & & \\
\hline runoff zone & Yin Zita & 27.94 & 48.31 & 18.08 & 15.75 & 16.88 & 257.5 & 7.6 & 195.07 & 403.99 & $\mathrm{~A}: \mathrm{HCO}_{3}-\mathrm{Na} \cdot \mathrm{Ca}$ \\
\hline
\end{tabular}




\begin{tabular}{|c|c|c|c|c|c|c|c|c|c|c|c|}
\hline & Tie Jiangpu & 35.16 & 66.81 & 21.83 & 29.92 & 66.68 & 278.4 & 7.65 & 256.71 & 511.1 & $\mathrm{~A}: \mathrm{HCO}_{3}-\mathrm{Na} \cdot \mathrm{Ca}$ \\
\hline runoff $\rightarrow$ & Da Huangpo & 59.3 & 82.2 & 28 & 67.4 & 122 & 275 & 7.5 & 320.5 & 635.9 & $\mathrm{~A}: \mathrm{HCO}_{3} \cdot \mathrm{Cl}-\mathrm{Na}$ \\
\hline \multirow{2}{*}{ weak runoff zone } & Yao Zhuang & 105 & 193 & 92.4 & 234 & 270 & 589 & 6.8 & 862.33 & 1485.9 & $\mathrm{~A}: \mathrm{HCO}_{3} \cdot \mathrm{Cl}-\mathrm{Na} \cdot \mathrm{Ca}$ \\
\hline & SJ & 5.64 & 87.53 & 31.45 & 41.33 & 146.8 & 166.7 & 7.52 & 348.05 & 492.91 & $\mathrm{~A}: \mathrm{HCO}_{3} \cdot \mathrm{Cl}-\mathrm{Ca} \cdot \mathrm{Mg}$ \\
\hline \multirow[t]{2}{*}{$\begin{array}{c}\text { weak runoff area } \rightarrow \\
\text { stagnant zone }\end{array}$} & $\mathrm{C}_{3}$ & 58.51 & 454 & 119.3 & 381 & 1052 & 137 & 7.2 & 1624.9 & 2202.7 & $\mathrm{~B}: \mathrm{Cl} \cdot \mathrm{SO}_{4}-\mathrm{Ca}$ \\
\hline & $\mathrm{C}_{2}$ & 152.3 & 126 & 37.96 & 327.5 & 202.9 & 137.1 & 7.65 & 470.95 & 986.56 & A: Cl-Na \\
\hline stagnant zone & $\mathrm{C}_{4}$ & 727.5 & 319.8 & 98.95 & 1463 & 531.2 & 126.5 & 7.46 & 1206.0 & 3267.3 & B: Cl-Na \\
\hline
\end{tabular}

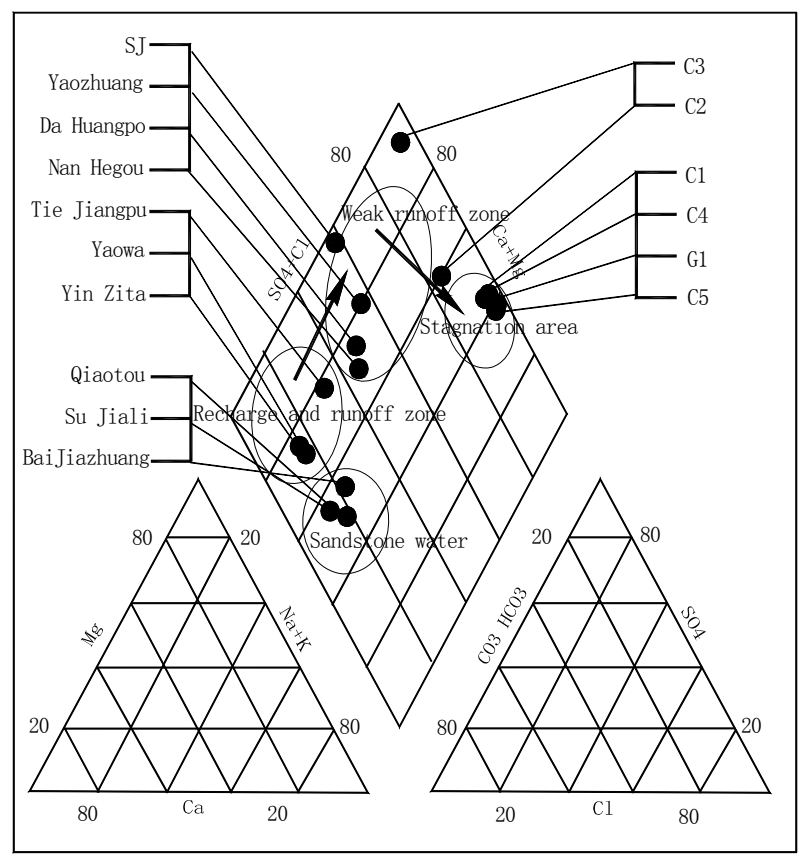

Figure 1. Piper trilinear nomograph

In runoff zone, the content of $\mathrm{HCO}_{3}{ }^{-}$is about $80 \%$. In weak runoff zone, the content of $\mathrm{Cl}^{-}$and $\mathrm{SO}_{4}{ }^{2-}$ is more than $40 \%$. In stagnant zone, the content of $\mathrm{Cl}^{-}$and $\mathrm{SO}_{4}{ }^{2-}$ is around $90 \%$. Sample points of different water quality types are distributed differently in the piper trilinear nomograph. Ordovician sample points around the periphery, such as Yao Wa, Yin Zita and Tie Jiangpu, are distributed in $\mathrm{HCO}_{3}-\mathrm{Ca} \bullet \mathrm{Mg}$ zone, which are on the left of the diamond graphic, and reflect water quality characteristics of runoff zone. g4 hole, Da Huangpo and Yaozhuang in the downstream are distributed in $\mathrm{HCO}_{3} \cdot \mathrm{SO}_{4}-\mathrm{Ca} \bullet \mathrm{Mg}$ zone, which are on the top of the diamond graphic, which is the area that transformed from runoff to weak runoff area. Within the coalfield, C4, g1, C1, and C5 Ordovician sample points are distributed in $\mathrm{Cl}-\mathrm{Na} \cdot \mathrm{Ca}$ zone, which are on the top right of the diamond graphic, and reflect water quality characteristics of stagnant zone. $\mathrm{C} 2$ and $\mathrm{C} 3$ Ordovician sample points are distributed in $\mathrm{SO}_{4} \cdot \mathrm{Cl}-\mathrm{Ca} \cdot \mathrm{Na}$ or $\mathrm{Cl} \cdot \mathrm{SO}_{4}-\mathrm{Ca} \bullet \mathrm{Na}$ zone, reflect water quality characteristics of weak ruoff zone, and are the transitional water types to stagnant zone. Coal sandstone sample points are distributed in $\mathrm{HCO}_{3}-\mathrm{Na} \cdot \mathrm{Ca} \cdot \mathrm{Mg}$ zone, which are on the top left of the diamond graphic ${ }^{[2]}$. Those are distributed obviously differently with Ordovician sample water types, so we can confirm that there has no hydraulic connection between Ordovician limestone aquifer and the upper coal sandstone aquifer. But other parts of the coalfield still have the possibility of this hydraulic connection. Those were shown in Fig.1.

We calculated the ratio of $\gamma \mathrm{Ca}^{2+} / \gamma \mathrm{Mg}^{2+}$ and $\gamma \mathrm{SO}_{4}{ }^{2-} / \gamma \mathrm{Cl}^{-}$of Ordovician groundwater in pumping test area $(\gamma$ is the milligram equivalent), and knew that: from SJ hole to $\mathrm{C} 5$, the content of $\mathrm{Ca}^{2+}$ increased from $82 \mathrm{mg} / 1$ to $500 \mathrm{mg} / \mathrm{l}$, the ratio of $\gamma \mathrm{Ca}^{2+} / \gamma \mathrm{Mg}^{2+}$ of carbonated groundwater increased from 1.53 to 1.99. Those ratios were all in the range of groundwater index of limestone regions, and reflected that: Ordovician groundwater here flowed through relatively pure limestone strata. Ratios continuously increased when flowing to the west, which reflected that Ordovician groundwater stagnated in the coalfield for a long time and the solubility degree of calcareous limestone increased continuously. At the same time and in the same direction, the ratio of $\gamma \mathrm{SO}_{4}{ }^{2-} / \gamma \mathrm{Cl}^{-}$reduced, and the content of $\mathrm{Cl}^{-}$increased greatly to $2700 \mathrm{mg} / \mathrm{l}$, which reflected that groundwater here was still going through the process of halite dissolving. water quality of $\mathrm{C} 3$ hole reflected the specific characteristics in that region: Exceptionally high content of $\mathrm{SO}_{4}{ }^{2-}$ with the concentration of $1051 \mathrm{mg} / \mathrm{l}$, which was 8 times of $\mathrm{Sj}$ hole, and more than 5 times of $\mathrm{C} 2$ and $\mathrm{C} 4$, and its $\mathrm{Ca}^{2+}$ content increased obviously. Those characteristics reflected nonuniformity of groundwater quality and yield in pumping area influenced by the lithology, structures and karst development of Ordovician limestone aquifer. Values concerned with the groundwater in carbonatite region or gypsum (or halite)-bearing region were shown as table 2 .

TABLE II. THE RATIO OF $\gamma \mathrm{Ca}^{2+} / \gamma \mathrm{Mg}^{2+}$ AND $\gamma \mathrm{SO}_{4}{ }^{2-} / \gamma \mathrm{Cl}^{-}$OF ORDOVICIAN LIMESTONE AQUIFER WATER IN PUMPING AREA

\begin{tabular}{ccccccc}
\hline $\begin{array}{c}\text { Holes } \\
\text { Index }\end{array}$ & $\mathrm{SJ}$ & $\mathrm{C} 3$ & $\mathrm{C} 2$ & $\mathrm{C} 4$ & $\mathrm{C} 1$ & $\mathrm{C} 5$ \\
\hline $\mathrm{Ca}^{2+} / \mathrm{mg} / 1$ & 82.14 & 454.03 & 127.93 & 319.82 & 507.69 & 457.82 \\
$\mathrm{Ca}^{2+}$ & 1.53 & 2.14 & 1.98 & 1.99 & 1.97 & 1.88 \\
$/ \gamma \mathrm{Mg}^{2+}$ & & & & & & \\
$\mathrm{Cl}^{-} / \mathrm{mg} / 1$ & 41.27 & 380.00 & 327.56 & 1648.14 & 2772.06 & 2524.19 \\
$\mathrm{SO}_{4}{ }^{2-} / \mathrm{mg} / 1$ & 132.48 & 1051.53 & 211.48 & 465.41 & 634.13 & 513.17 \\
$\gamma \mathrm{SO}_{4}{ }^{2-} / \gamma \mathrm{Cl}^{-}$ & 2.49 & 1.86 & 0.38 & 0.19 & 0.16 & 0.14 \\
\hline
\end{tabular}

\section{ANALYSIS ON RUNOFF CHARACTERISTICS OF ORDOVICIAN LIMESTONE GROUNDWATER}

Based on those analysis and data above, we delineated Ordovician groundwater chemical sub-regions of the study area, which were shown as Fig. 2.

Ordovician limestone groundwater flowed from the northeast, the east and the north to Tianqiao Spring discharge 
spot, with the hydraulic gradient of $4 \%$ o $6 \%$, which was steep in recharge area, and gradually became gently to the discharge spots. From the east to the west of the mine field, Ordovician limestone aquifer buried deeper. Quality type of Ordovician water changed from $\mathrm{HCO}_{3}-\mathrm{Ca} \bullet \mathrm{Mg}$ (Yin Zita in the recharge area) to $\mathrm{HCO}_{3} \cdot \mathrm{SO}_{4}-\mathrm{Ca} \bullet \mathrm{Mg}$, the content of dissolvable karst chlorides and sulfate increased, and so was the mineralization. In the north of TianQiao Springs, Ordovician limestone groundwater flowed into the deep, and the ruoff became slow and even sluggish, the water type showed the characteristics of Ordovician limestone groundwater in stagnant zone.

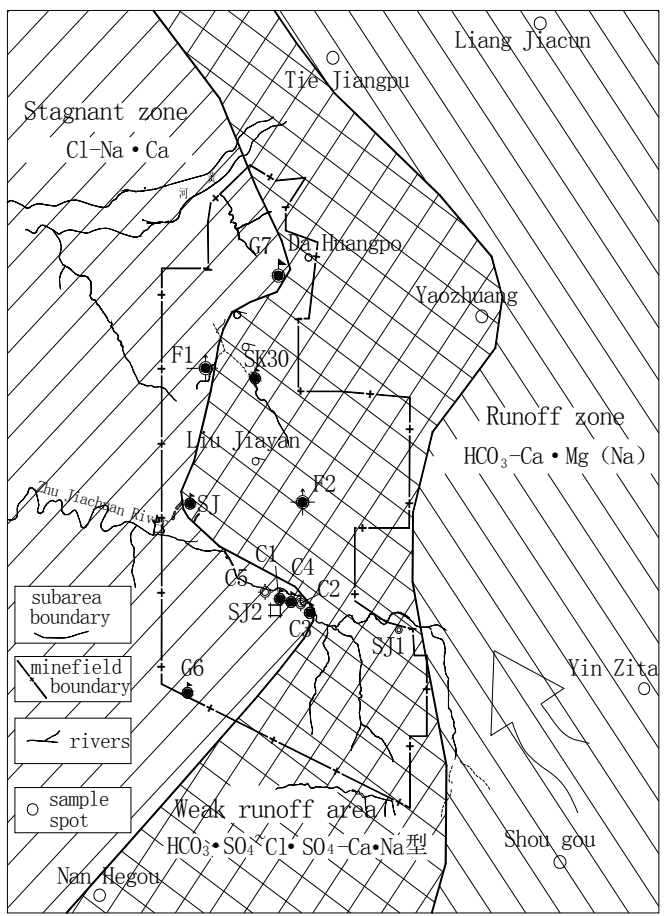

Figure 2. The subarea map of water quality

\section{CONCLUSIONS}

Through analysis on pumping test and draining test data, we got runoff characteristics of the Ordovician limestone karst water: From the east to the west, the coalfield was divided into runoff zone $\rightarrow$ weak runoff zone $\rightarrow$ stagnant zone. To the east of Yin Zita and Yaowa, where Ordovician limestone outcrops, the limestone is supplied by atmospheric precipitation and surface water infiltration. On the whole, Ordovician limestone groundwater flowed from the northeast, the east and the north to Tianqiao Spring discharge spot. Within the coalfield, Ordovician limestone groundwater is in a relatively closing and lagging condition, with weak supplying conditions and gentle hydraulic gradient. So Ordovician limestone water quality here is basically remained natural and original that isn't disturbed by human beings.

\section{REFERENCES}

[1] CAO Xiao-hu. Analysis on Chemical Character of Groundwater in the Mine Field of Shuangliu Area[J]. Ground Water, 2009, 31(4): 36-38.

[2] Wang Shasha. Evaluation of the Ordovician limestone water enrichment and water inrush risks of the NO.11 coal seam floor in Jinmen Coal mine. SDUST, 2011 